\title{
Propagandanın Filmi: Yeşil Bereliler
}

The Film of Propaganda: Green Berets

\author{
Doç. Dr. Serkan Öztürk ${ }^{1}$ - Sezen Altay ${ }^{2}$
}

Başvuru Tarihi: 09.05.2019

Kabul Tarihi: 12.06.2019

\section{Öz}

Propaganda kitleleri ikna etme ve yönlendirme amacı taşıyan yöntemlerin tümünü ifade etmekte ve bu amaçla kullanılan kitle iletişim araçları birer propaganda aracı olarak kabul edilmektedir. Toplumların arasındaki iletişimin artması ile birlikte belirli kimse ya da çevrelerin insanları yönetme, hükmetme arzusu farklı propaganda yöntemlerinin ortaya çıkmasına neden olmuş ve bu bağlamda geniş kitlelere hitap eden ve insanlar arasında bir eğlence aracı olarak görülen sinema sanatından faydalanmışlardır. Ortaya çıktığı günden bugüne kadar farklı ideolojik ve politik hedefler doğrultusunda propaganda aracı olarak kullanılan sinemanın en önemli temsilcilerinden birisi Hollywood sinemasıdır. Özellikle filmleriyle savaş dönemlerinde kendinden söz ettiren Hollywood sineması bu şekilde kitleler üzerinde siyasi, askeri ve kültürel propaganda faaliyetlerine devam etmektedir. Çalışmamızın amacı literatür taraması ve içerik analizi ile elde edilen propaganda kavramıyla ilgili bilgiler ışı̆̆ında 'Yeşil Bereliler' filmi örnek gösterilerek Hollywood sinemasının bir propaganda aracı olarak kullanıldı̆̆ını ve sinemanın toplum üzerindeki etkisini ortaya koymaktadır.

Anahtar Kelimeler: Propaganda, Sinema, Hollywood, Yeşil Bereliler

\begin{abstract}
Propaganda refers to all of the methods aimed at convincing and guiding the masses, and the mass media used for this purpose are accepted as propaganda tools. With the increase of communication among societies, the desire of certain people or circles to govern, to rule people has led to the emergence of different methods of propaganda and in this context, they have benefited from the art of cinema, which has appealed to a wide audience and is seen as an entertainment tool among people. Hollywood cinema is one of the most important representatives of cinema, which has been used as a propaganda tool in line with different ideological and political goals
\end{abstract}

\footnotetext{
${ }^{1}$ Yalova Üniversitesi, Sanat ve Tasarım Fakültesi, serkan.ozturk@yalova.edu.tr, ORCID: 0000-0001-8882-3607

${ }^{2}$ Ordu Üniversitesi Sosyal Bilimler Enstitüsü, altaysezen@gmail.com, ORCID: 0000000309986200
} 
since its emergence. The Hollywood cinema, which has made its mark especially during the war with its films, continues its political, military and cultural propaganda activities on the masses. The aim of our study is to show how the film 'Green Berets' is used as a propaganda tool and shows the effect of cinema on society in the light of literature review and content analysis.

Keywords: Propaganda, Cinema, Hollywood, Green Berets

\section{Giriş}

İnsanlığın varoluşundan beri süregelen kontrol etme isteği, zamanla toplumlar üzerinde propaganda kavramını ortaya çıkarmış ve egemen güçler bunu çeşitli yöntemler ile kullanarak kendi çıkarları doğrultusunda ideolojik görüşlerini halka empoze etmeye çalışmıştır. Kendini daha çok siyasi ve kültürel alanlarda belli eden propagandanın var oluş sebebi özünde ekonomik çıkarlara dayanmaktadır. Bu doğrultuda uygulanan politikalar ve tutumlar, tamamen halkı ikna etme, inandırma ya da yanıltma esaslıdır. Kitle iletişim araçlarının yaygınlaşması ile küresel anlamda güçlenen propaganda uygulamaları, teknolojinin gelişmesi ile farklı alanlarla da kullanılmaya başlanmış ve bugün bile günlük yaşamlarımıza dâhil olan her yeni teknolojik yenilik birer propaganda aracı olarak etkin bir şekilde kullanılmaya devam etmektedir. Önceleri gazete, radyo ve televizyon gibi kitle iletişim araçları ile başlayan propaganda uygulamaları, günümüzde sıklıkla internet üzerinde veya sinema filmlerinde karşımıza çıkmaktadır. Geçmiş yıllara bakıldığında özellikle savaş dönemlerinde kendini belli eden askeri ve siyasi propaganda, egemen güçler tarafından silahlanma ve savaş sanayisinin sermayesini elde edebilmek için uygulandığı görülmektedir. Kitlelerin algı yapılarını kontrol etme ihtiyacı ile uygulanan bu çalışmalar sadece askeri, ekonomik ve siyasi alanlarda değil, kültürel ve sosyal alanlarda da karşımıza çıkmaktadır. Savaş zamanlarının yanı sıra belli bir norm ya da kültüre sahip olan topluluklara karşı devlet politikaları doğrultusunda ötekileştirmek, dışlamak gibi amaçlarla da propaganda çalışmaları yapılmaktadır. Propaganda amacı ile uygulanan yöntem ve teknikler, planlandığı gibi yapıldığı takdirde insanların davranışlarını, tutumlarını ve hatta düşüncelerini istenen yönde değiştirebilir. Bu nedenle özellikle ülkeler arasında daha çok dostane bir ilişki olarak gözlemlenen diyaloglar aslında en tehlikeli propaganda biçimi olan kültürel ve ekonomik propagandadır. Bunların dışında propaganda türlerine genel olarak bakıldığında silahlı bir saldırı ya da savaş dönemlerinde görülen askeri propaganda dışında siyasi propaganda ise daha çok devlet yönetimi ve yargı organlarını hedef alan diplomatik ilişkiler çerçevesinde karşımıza çıkmaktadır. İktidarın devrilmesi veya demokratik seçimlerde uygulanan propaganda yöntemleri, devletin rejimlerine ve ideolojilerine göre değişkenlik göstermektedir. $\mathrm{Bu}$ yöntemler 20.yy'da teknolojinin gelişmesi ve küresel iletişimin artmasıyla birlikte gazete, el broşürleri gibi yazılı iletişim araçlarını bir kenara bırakıp yerini sinema gibi görsel iletişim kanallarında uygulanmaya başlanmıştır. Sinema sanatı, ortaya çıktığı günden bu yana insanların ilgisini çekmiş ve milyonlarca insanı beyaz perdede etkisi altına almış kitle iletişim araçlarından birisidir. İnsanları hem eğlendirip hem de hoşça zaman geçirmesini sağlayan sinema filmleri, propagandacılar tarafından toplumun bilinçaltına belirli mesajlar göndermek için bir firsat olarak görmüşler ve özellikle savaş dönemlerinde egemen güçler kendi hedefleri 
ve çıkarları doğrultusunda propaganda yöntemlerini farklı tekniklerle ve ustalıkla uygulamışlardır. Bu bağlamda en büyük propaganda endüstrilerinden biri olarak görülen Hollywood sinemasının günden güne büyüyüp filmlerinin dünya çapında gösterilmesi, Amerika'yı, propagandayı en etkili kullanan ülkelerden birisi haline getirmiştir. Oldukça büyük bir pazar alanına sahip olan Hollywood sinemasının bazı çevreler ya da kişiler tarafından önceden belirlenmiş amaçlar doğrultusunda kullanıldığı ve kontrol edildiği bilinmekte ve çalışmamızda 'Yeşil Bereliler' filmi örnek gösterilerek Amerika'nın Hollywood üzerinden uyguladığı propaganda yöntemleri ele alınmaktadır. Bu nedenle literatür taramasından yola çıkılarak ulaşılan bilgiler, film üzerinde incelenen içerik ve sahne analizleriyle desteklenmiştir. Çalışmamızın birinci bölümünde propagandanın tanımı ve yöntemleri açıklanarak uygulanan teknikler hakkında bilgiler verilmiştir. İkinci bölümde, sinemanın propaganda ile ilişkisi açıklanarak Amerika'nın Hollywood sinemasını propaganda aracı olarak kullanması ele alınmıştır. Üçüncü bölümde ise 'Yeşil Bereliler' filmi Hollywood ve propaganda sineması bağlamında incelenecektir.

\section{Propaganda}

Propaganda söylemi toplulukların ilk oluşmaya başlamasıyla bilinmekte ancak buna rağmen propaganda kelimesinin ilk kullanımının 17. yy’da gerçekleştiği bilinmektedir. Öncesinde eski Yunan, Roma gibi ortaçağ dönemlerinde kullanılan bir yöntem olarak propaganda, bir çok devlet tarafından manipülasyon aracı olarak kullanılmıştır. Sezar’ın madeni para basarak imparatorluğun büyük bir bölümüne dağıtması ilk kitlesel propaganda aracı olarak kabul edilebilir'(Bektaş, 2002, s. 71). Mısır'daki piramitler, Roma'nın Lejyonlarında düzen ve gösterişlilik, Kuzey Amerika'daki kabilelerin totemlerle süslü ağaçtan sütunları, bu topluluklardaki liderliklerin güçlü görünmelerini pekiştirmek, topluluk üyelerinin aidiyet duygusunu güçlendirmek için kullanılmış propaganda düzenekleriydi' (İnceoğlu, 1985, s. 63). 17.yy’a kadar iktidar ve savaş mücadeleleri haricinde dini otorite sağlamak için kullanılan propaganda, günümüzde devletlerin demokratik süreçlerinin başlamasiyla birlikte siyasi alanlarda da görülmeye başlanmıştır. Kelime anlamı Latince 'propagare' kökünden gelen, Türk Dil Kurumu tarafından 'bir öğreti, düşünce veya inancı başkalarına tanıtmak, benimsetmek ve yaymak amacıyla söz, yazı vb. yollarla gerçekleştirilen çalışma' olarak tanımı yapılan 'propaganda, önemli fikirleri desteklemek anlamında olup; Latince'de aynı zamanda tohum ekmek anlamında kullanılmaktadır'(Jowett ve O’Donnell, 2012, s. 2). Bir görüşü veya ideolojiyi yansıtmak ya da fikir söylemini bilinçli olarak insanların zihnine yerleştirmek için hazırlanan propaganda çalışmaları, halkın psikolojisini planlanmış bir yöne doğru çekmek için uygulanmaktadır. Daha çok hile, yalan ve manipüle gibi sözcüklerin karşılığı olan propaganda, her zaman belirli hedefler doğrultusunda bir amaca hizmet etmektedir. Özellikle kitle iletişim araçlarının faaliyetlerinin günümüz teknolojisinde artmasıyla birlikte hız kazanan propaganda çalışmaları güç kazanmıştır. ‘...özellikle birtakım semboller, söz, hareket, jest, müzik ve diğer bir takım araçlar propagandanın kitle iletişim araçlarındaki kullanımını ve etkisini artırmaktadır'(Bıçakçı, 2003, s. 110). Bilgiler ve görsel öğeler bir arada kullanılarak kitlenin üzerinde propagandası yapılan konuya yönelik bir istek uyandırılır ve kitlenin bu yönde 
harekete geçmesi sağlanır (Bektaş, 2002, s. 119). Kullanılan propaganda çalışmalarının yöntemleri zaman zaman değişse bile amacı daima aynı kalmıştır. Ancak 'propaganda, şartları değiştiremez, sadece bu şartlar altındaki inançları değiştirebilir; insanları inançlarını değiştirmeye zorlayamaz, fakat sadece, onları böyle yapmaya ikna edebilir' (Lerner, 2000, s. 270). Propaganda uygulamalarının başarı sağlayabilmesi için hedef kitle iyi tanınmalı ve uzak durulması gereken noktalardan kaçınmak gerekmektedir. Böylece insanların algıları üzerinde bir hâkimiyet kurarak hedeflenen amaca ulaşılabilecektir. Günümüzde sosyal medya gibi kitle iletişim araçlarının kullanımının fazla olması ve 20. yüzyılın ekonomik sorunları nedeniyle toplumun yaşadığı buhran ve depresyon insanları, manipüle etme yolunda daha açık bir hedef haline getirmiştir. Hedef kitleyi etkilemek için yapılan propaganda çalışmaları, uygulanan teknik ve yöntemlere göre türlere ayrılmaktadır. Bu türler birbirinden bağımsız bir şekilde kullanılabileceği gibi bir arada da uygulanabilmektedir. Çalışmamızda propaganda kaynakların, amacına ve konularına göre üç türde ele alınmaktadır.

\section{Kaynaklarına Göre Propaganda}

Kaynaklarına göre propaganda yöntemleri kendi içerisinde beyaz, gri, kara, silahlı ve karma olarak beşe ayrılmaktadır. Beyaz Propaganda, kaynağı belli olan, açık, güvenilir, şeffaf olup, doğruluğa önem veren propaganda çeşididir. İftiraya, yalan habere gerek kalmadan kendini saklamak istemeden propaganda yapan kişinin kaynağı, genellikle resmidir ve kamuoyunu bilinçlendirme amacı gütmektedir. 'Dolayısıyla konusu, nasıl ve ne şekilde yapılacağı ve hangi kitleye dönük uygulanacağı konusunda bir bilinmezliğin aksine herkesçe kolaylıkla bilinebilecek bir yapıya sahiptir' (Tarhan, 2006, s. 37). Beyaz propagandanın genellikle vatanseverlik, milliyetçilik gibi ulusal değerleri ön plana çıkarmak için kullanıldığ görülmektedir. Hitler Dönemi’nde I. Dünya Savaşı sonrasında radyolardan yapılan Alman ırkının üstünlüğünü anlatan söylemleri beyaz propagandaya örnek gösterilebilir. Gri propaganda ise doğruluğu ispatlanmamış söylemleri yaymak için uygulanan bir propaganda tekniği olarak bilinmektedir. Bu nedenden dolayı daha çok rivayet ve şayialara dayanan gri propagandanın kaynağı gizli tutulur ve verilen mesajlar abartılı bir üslupla çarpıtılarak kitlelere iletilir. Amacı toplum içinde şüphe yaratmak ve güven zedelemeye çalışmaktır. Kaynağının belirli ve net olmamasından dolayı doğruluğu ispatlanamaz durumdadır. Bu yüzden çoğunlukla toplumun ilgisini çekecek konularda gri propaganda yapılmaktadır. 'Neyin yalan neyin gerçek olduğu; söylenenlerin kim tarafından ne zaman ve ne şekilde söylendiği alabildiğine belirsiz olduğundan, çoğu kez muhatapları açısından en tehlikeli propaganda olarak tarif edilmektedir' (Yaman, 2007, s. 40). Sovyet Rusya ve Amerika Birleşik Devletleri arasında soğuk savaş dönemi olarak bilinen dönemde ülkelerin birbirleri ile ilgili asılsız haberlerin gündeme gelmesi gri propaganda örneği olarak gösterilebilir. Günümüzde internet gibi sosyal medya araçlarının sıklıkla kullanılıyor olması gri propaganda yapabilmek adına önemli bir silah haline gelmiştir. Kara propaganda ise tamamen gerçeği çarpitarak hedefi şaşırtmak amacıyla uygulanan bir yöntem olarak bilinmektedir. Yalan, iftira ve hile içeren kara propaganda, çeşitli dini ve siyasi ideolojileri yayma durumlarında kullanılmaktadır. Toplumda genellikle kaos durumlarında kendini gösteren kara propagandanın kaynağını gizli tutulur ve toplumda kabul görmüş her 
türlü fikri veya düşünceyi yerle bir ederek zamanla sosyal bağları zayıflatmak amacı güder. Kara propaganda, kurumların ve devletin güvenirliğini sorgulatmayı amaçlarken, gri propagandanın amacı sadece kafa karıştırmaktır. Silahlı propaganda devletin var olan düzenini bozmak isteyen terör örgütlerinin hedeflerine ulaşabilmek yaptıkları silahlı güç eylemlerini kapsamaktadır. Diplomatik ya da belirli kişilere suikast düzenlemek, halka açık bölgelere bomba yerleştirmek gibi uygulamalar silahlı propaganda içinde yer almaktadır. Son olarak Karma propaganda ise ortak çıkarlar doğrultusunda beyaz, gri, kara ve silahlı propaganda yöntemlerini aynı anda kullanması anlamı taşımaktadır. Uzun vadeli ve planlanmış bir yöntem olan karma propagandanın başarıya ulaşması sonucunda arkasında küresel anlamda sansasyonel bir etki bırakmaktadır. Bu propaganda yönteminin kullanıldı̆̆ 1 tarihte bilinen en büyük olay 11 Eylül saldırılarıdır.

\section{Amacına Göre Propaganda}

Amacına göre propaganda yöntemleri kendi içerisinde stratejik, taktik, takviye amaçlı destek ve provokasyon amaçlı tahrikçi propaganda olarak dörde ayrılmaktadır. Stratejik Propaganda, uzun vadede planlanan ve sıklıkla devlet politikalarının uzun vadeli planları için kullanılmaktadır. Geniş bir kitleye hitap eden bu propaganda çeşidi, toplumların düşünce algılarını değiştirmek üzerine kuruludur.

Lasswell stratejik propaganda ile ilgili uyulması gereken dört aşamanın varlığından bize bahseder. Birinci aşamada amaç olarak düşman bir caniymiş gibi kitlelere lanse edilecek ve ona karşı toplumsal destek yerine topyekûn bir nefret hali oluşturulmaya çalışılacaktır. İkinci aşamada propagandaya müttefikler kazanmak maksadıyla ortak çıkarlar önlenecek ve bu konuda propaganda yapan tarafında düşman karşısında diğer ülkeler gibi düşündüğüne kitleler ikna edilecektir. Üçüncü aşamada; yürütülen propagandaya tarafsız olan güçlerin dostluğu sağlanacak, propagandaya konu olmayan tüm alanlarda ortak bir iş birliği sağlanması yoluna gidilecektir. Dördüncü ve son aşamada ise düşman tarafın liderlerinin halkın gözünde küçük düşürülmesi hedeflenecek, böylece hem iktidarın hem de halkın moral seviyesi sıfırlanmış olacaktır (Aktaran: Yaman, 2007, s. 28-29).

Lasswell'in açıkladığı stratejik propagandayı Adolf Hitler’in 2. Dünya Savaşı öncesinde halkı savaşa ikna etmek için uyguladığı görülmektedir. Medya dünyasında bulunan eşik bekçileri sayesinde medya patronlarına ve iktidara yönelik yapılan yanlı düşüncelerin halka yansıtılması sonucu toplum günümüzde hala yönlendirilmeye devam edilmektedir. Stratejik propaganda yönteminin işe yaraması için kullanılan kısa vadeli Taktik Propaganda, sonuç alabilmek için ya da uzun vadeli planın bozulmaması adına yapılan uygulamaları içermektedir. Örneğin Osmanlıların savaş açtıkları veya açacakları devletin içinde halkın içine karışarak yerel halka Osmanlı Devleti'nin daha iyi ve daha güvenilir olduğu anlatılarak, savaş zamanı halkın Osmanlı tarafına çekilmesi amaçlamıştır. Bu bağlamda, taktik propagandanın hedefi karşı tarafın 
moralini bozmak, güveni sarsmak ve korkutmak olmuştur. Halkın düşüncelerinin değişmesi, ileri dönemde stratejik propagandanın tamamlaması konusunda önemli rol oynamaktadır. Takviye Amaçlı Destek Propaganda, sonuç almaya yönelik destek propaganda aşaması olarak tanımlanmaktadır. Bu yöntem hedefe yakın zamanda ulaşabilmek ya da devamlılığını sağlamak adına uygulanmaktadır. 2. Körfez Savaşı sırasında Arap medyasının destekleyici propaganda da rol üstlenmesi ve savaşta olup bitenler, ABD’li askerler tarafından kaleme alınıp Arap yazarlar aracılığı ile yerel ve ulusal Irak basınına verilmesi, destek propaganda örneği sayılabilir. Bu süreç boyunca bir takım Arap yazarlar da maddi imkânlar vaat edilmek suretiyle işgalin haklı olduğu yönünde ve işgal kuvvetlerini destekler mahiyette yazılar yazmaları yönünde ikna edilmişlerdir (aktaran: Yaman, 2007, s. 33). Son olarak Provokasyon Amaçl Tahrikçi Propaganda ise hileye dayalı bir yöntem ile hedef kitleyi belli bir yönde harekete geçirmek amacıyla yapılan eylemleri ifade etmektedir. Sıklıkla toplumu ideolojik olarak bölme hedefi olan provokasyon amaçlı propaganda yöntemi, halkı herhangi bir konuda cesaretlendirerek toplumu karmaşaya sürüklemek amacıyla kullanılmaktadır. Propaganda, inanç ve fikir değişimi iken tahrikçi propaganda, bunu eylem haline dönüşümü olarak tanımlanmaktadır. Bolşevik ihtilali sırasında Lenin, amacına ulaşmak için bu yöntemi kullanmış ve başarı elde etmiştir. 'Propagandacı, bir tek kişiye ya da küçük topluluklara birçok düşünce aşılarken, kışkırtıcı bir tek düşünceyi büyük bir insan kitlesine aşılamaya çalışmaktadır' (aktaran: Doğan, 2014, s. 37).

\section{Konusuna Göre Propaganda}

Konusuna göre propaganda yöntemleri kendi içerisinde siyasi, askeri, kültürel, ekonomik ve karşı propaganda olarak beşe ayrılmaktadır. Siyasi propaganda egemen güçlerin istekleri doğrultusunda hareket eden mevcut iktidarları korumak ya da güçlendirmek için yaptığı çalışmaları kapsamaktadır. Diplomatik süreçleri kapsayan siyasi propaganda, sıklıkla seçim dönemlerinde karşımıza çıkmaktadır. Zaman zaman savaş dönemlerinde gidişatı değiştiren siyasi propagandaya bilenen en önemli örnek 1. Dünya Savaşı sırasında Amerika Birleşik Devletleri tarafından yayınlanan Wilson İlkeleridir. İletişim alanında çalışmaları bulunan yazar Alvin Toffler siyasi propaganda sürecini şu sözlerle ifade etmektedir:

Bunlar insanın zihnini burmak için kullanılan kerpetenler gibidir. Bunlardan en yaygını zulüm suçlamasıdır. İkinci araç, savaştaki kozları abartmalı bir şekilde şişirmektir. Üçüncü, zihin burma aracı, hasmın şeytanlaştırılması veya insanlıktan uzaklaştırılmasıdır. Dördüncü bir araç "Bizimle olmayanlar bize karşıdır” mantığı ile kutuplaştırmadır. Beşincisi, kutsal onaya sahip olma iddiasıdır (akt: Yılmaz, 2006: 151).

Askeri propaganda, var olan yönetime veya iktidara karşı olabilecek tüm tehditlere yönelik iç ve dış sahalarda yapılan güç gösterilerini ifade etmektedir. Düşman karşısında dik durmak ve birlik beraberlik içinde duruşun karşılığı olan askeri propagandanın amacı, devlet bütünlüğü yansitmaktır. 'Askeri propaganda en temel anlamıla devletlerin silahlı kuvvetleri desteklemek ve caydırıcı gücünü dış tehditlere karşı kullanmak bağlamında yaptığı propagandadır’ (Özsoy, 
1998, s. 20). Savaş propagandası olarak görülen askeri propaganda, sıklıkla kara propaganda yöntemine başvurmakta ve kaynağını belirsiz tutmaktadır. Özellikle savaş dönemlerinde bu şekilde düşmanın moralini bozup, savaşın gidişatını değiştirmek hedeflenmiştir. Kültürel Propaganda, teknoloji ile doğru orantıda büyüyen bir propaganda yöntemidir. Günlük yaşam alanının hemen hemen her yerinde kendini gösteren kültürel propaganda, bir toplumun başka bir topluma kendi kültür ve değerlerini empoze etme eylemlerini içermektedir. Bu yöntem ile toplum, başka bir milletin sempatisini kazanarak birçok siyasi amaca ulaşmayı hedeflemektedir. Tarihte batılı devletlerin farklı ülkelerde okullar açması örneğinden yola çıkarak o ülke içerisinde yaşayan yerel halka kendi değerlerini ve kültürünü aşılaması bir kültürel propaganda örneğidir. Bir bakıma dostluk ilişkisi gibi görünen kültürel propaganda, sanat veya eğitim gibi birçok etkinlikte yer almakta ve gelişmiş ülkelerin siyasi ve ekonomik çıkarları sebebiyle bu propaganda çeşidine başvurduğu gözlemlenmektedir.

Üçüncü dünya ülkelerinin birçoğu dışarıdan gelişme modelleri ve teknoloji alarak, fakat aynı zamanda kendi kültürel özelliklerini koruyarak kalkınma fikrini savunmaktadır. Her ne kadar masum bir hedef olarak görülse de bunu başarabilmiş üçüncü dünya ülkesi yoktur. Bu durum da kültürel propagandanın bu alanda ne kadar başarılı kullanıldı̆̆ının bir kanıtıdır (Yılmaz, 2006, s. 2).

Ekonomik Propaganda, ülkelerin dış politikalarında maddi menfaatini göz önüne alarak yaptıkları çalışmaları içermektedir. Uluslararası ilişkilerde bir devletin ekonomisi, o ülkenin refah seviyesini ve uluslararası platformda yerini belirlemektedir. Dolayısıyla ekonomik propaganda, diğer devletleri maddi açıdan zayıflatıp kendini güçlü kılmayı hedeflemektedir. Özellikle savaş sonrası ülkelerin kalkınmaya devam edebilmesi için bu propaganda yöntemine başvurulmaktadır. Son olarak Karşı Propaganda ise uygulanan bir propaganda çalışmasının doğru olmadığını ispatlamak için muhalif güçler tarafından yapılan propaganda çalışmalarını kapsamaktadır. Karşı tarafın doğrularını çürütmek için uygulanan Karşı Propaganda, sıklıkla seçim zamanlarında ya da savaş dönemlerinde karşımıza çıkmaktadır. Diğer bir karşı propaganda şekli ise toplumun dikkatini başka bir yöne çekerek iktidara başka bir propaganda malzemesi vermektir. 'Kendi görüşlerini yaymak isteyenler, bir yandan da karşıdakilerin görüşlerini çürütmeye çalışırlar'(Bektaş, 2002, s. 209). Özetle tüm propaganda yöntemleri insanların düşüncelerini ve algılarını değiştirmek amacıyla yapılan çalışmaları ifade etmektedir. $\mathrm{Bu}$ amaç doğrultusunda gazete, televizyon ve radyo gibi kitle iletişim araçları dışında insanları hipnotize ettiği ispatlanmış bir sanat dalı olan sinema, egemen güçler tarafından oldukça güçlü bir propaganda aracı haline getirilmiştir.

\section{Hollywood Sineması ve Propaganda}

İnsanların bilinçaltına etki etmeyi başarabilen günümüzün en genç sanat disiplinlerinden birisi olan sinema, teknolojinin gelişmesiyle birlikte insanları hem eğlendirip hem de eğitebilen iletişim araçlarından biridir. İlk ortaya çıktığı andan itibaren propaganda amaçlı kullanılan sinema, yaşantımızdan aldığı gerçek kesitleri kurmaca olarak sunmakta ve hangi sanattan 
faydalanırsa faydalansın propaganda yapmaya devam etmektedir. Sinemanın diğer kitle iletişim araçlarına göre insanların üzerindeki etkisi daha fazla olduğu ispatlandığ 1 için egemen güçler veya kişiler bundan faydalanmak istemişlerdir. Teknolojinin ilerlemesi ve filmlerin kolayca çoğaltılıp dağıtılabilmesi, sinemayı propaganda için uygun hale getirmiş ve daha fazla kitleye ulaşma imkânı tanımıştır. Özellikle savaş dönemlerinde askeri bütünlüğü ve milliyetçilik gibi duyguları canlandırmak için kullanılan sinema, egemen ülkeler için lehte bir durum oluşturmaktadır. Sinemanın bu kadar etkili olabilmesinin sebebi, filmde yer alan karakter ile izleyicinin özdeşleşmesi ve karakterin fikirlerini kendisininmiş gibi kabul etmesidir. Eski dönemde televizyon gibi kitle iletişim araçlarının her yerde olmaması, insanların sinemaya gitmesine neden olmuş ve egemen güçler bundan faydalanarak sinemayı bir propaganda aracı olarak kullanmışlardır. 'Sinema, stratejik düşüncenin gücüne veya ortak hafızanın çok çabuk unutması özelliğine, sinema sanatının görsellik gerçeğini ve yoğunluğunu katarak, hayal edilen alternatif bir hikâye meydana getirmekte ve stratejik gündemin pozitif yönde söz konusu edilmesine veya mükemmelleştirilmesine yardımcı olacak zihni dünyanın oluşumunu ortak seyir yoluyla sağlamaktadır' (Valantin, 2006, s. 11). Sinemanın propaganda aracı olarak kullanılmasıyla ilgili Almanya ve Sovyet Rusya gibi bazı devletler bünyelerinde ufak birimler oluşturarak, halkın moralini yüksek tutmak ve milli bütünlüğü sağlamak istemişlerdir. 1925 yılında ilk siyasi propaganda filmi Sergei Eisenstein tarafından çekilmiş ve 'Potemkin Zırhlısı' adlı bu film, Çarlık Rusya döneminde yaşanan devrimde ezilen halkı konu edinmektedir. Çoğunlukla Almanya'da Nazi döneminde ve Sovyet Rusya döneminde karşımıza çıkan savaş, askeri ve siyasi propaganda filmleri, devlet yönetimi tarafından bir silah gibi kullanılırken, İngiltere ve İtalya gibi ülkelerde daha çok belgesel niteliğinde filmler çekildiği görülmektedir. Diğer devletlerin yanı sıra sinemayı etkin bir şekilde propaganda aracı olarak kullanan Amerika Birleşik Devletleri, günümüzün en büyük sinema endüstrisi olan Hollywood sinemasını kontrol etmekte ve filmleriyle toplumları etkisi altına almayı başarmaktadır. Bilinçli bir şekilde kendi kültürünü ve yaşam tarzını küresel anlamda tanıtmayı hedeflemiş ve tek tip dünya idealini oluşturmak için çabalamaya devam etmektedir. Sinemanın yanı sıra tüm olanaklardan faydalanan Amerika, özellikle eski savaş dönemlerinde askeri kaynak ve savaş sermayesi elde edebilmek için yoğun bir şekilde asker temalı filmler çekmiş ve içinde bulunduğu tüm tarihsel olaylarda durumu kamuoyunda kendi lehine çevirmeyi başarmıştır. Çekilen bu filmlerin dünyanın her yerine yüz binlerce kopyasını dağıtan Amerika, savaş görüntülerinden oluşan yaklaşık üç binden fazla film çekmiştir. Bu sayede her hafta sinemalara giden elli milyon Amerikan vatandaşına tam bir haber propagandasının yapılmasını sağlamış, Hollywood'da İkinci Dünya Savaşı'nı konu alan filmlerin çekilmesine destek veren politikaların planlayıcısı olmuştur (Yaman,2007, s. 92). Amerikan propagandası yapan Hollywood'a karşı diğer bölgelerde sıklıkla dini propaganda yapıldığı görülmektedir. Bu doğrultuda çekilen filmler sanatsal kaygılar yerine daha çok bir amacın gerçekleşmesi için yapılan çalışmalar olmuştur. Kendi görüş, düşünüş ve yaşam tarzlarını aktarmak ve empoze etmek isterken insanlar sinemayı kullanırlar. Buna propaganda sineması denmektedir (Odabaş, 2007). Ek olarak propaganda sineması için Dorsay şu ifadeleri kullanmaktadır: 
Propaganda sineması, görüldüğü üzere, sanatın asıl ve öz işlevine ters düşen bir sinemadır, çünkü insana sırt çevirmiştir bu sinema; insanın, kitlelerin tutsaklığını, kör bağlılığını, gerçeklerden uzaklığını sağlamaktadır. Her türlü ideoloji sinemayı bir propaganda aracı olarak kullanmayı düşünmüş ve denemiştir (Dorsay, 1984, s. 49).

Hollywood propagandası öncesinde, sinemanın ilk propaganda örneklerini veren Sovyet Rusya, Nazi Almanya'sı, Faşist İtalya, İspanya ve Fransa olmuştur. Hâkim ideolojinin ve iktidarın devam etmesi için alenen propaganda çalışmaları yapan bu devletlere karşı, Amerikan sineması Hollywood ile birlikte propagandaya yeni bir bakış açısı kazandırmıştır. Sinema her ne kadar Almanya ve Sovyet Rusya'da bir silah gibi propaganda amaçlı kullanılsa da 1990'dan sonra bu devletlerde propaganda sineması yok olurken, Amerika Birleşik Devletleri bünyesinde Hollywood sineması bir endüstri haline gelmeyi başarmıştır. 1. Dünya savaşı sırasında sinemanın propaganda gücünü ilk olarak fark eden Amerika, 2. Dünya savaşı sırasında yoğun bir şekilde sinema üzerinden propaganda faaliyetlerinde bulunmuştur. O dönemde Müslüman karşıtı olarak art arda çektiği yüzlerce film, bu çalışmalara örnek gösterilebilir. Filmlerde Müslüman halk sadece çöllerde yaşayan ya da birbirini öldüren ve hatta esir ticareti yapan yoksul bir halk olarak gösterilmektedir.

Özellikle 11 Eylül 2001 tarihi, ABD sinema endüstrisi için bir milat oldu. Zira o tarihe kadar, iyi adamın karşısındaki düşman karakteri, ekseriyetle Rus prototipiydi. 11 Eylül tarihinden sonra ise, Arap ırkına mensup Müslüman tipolojisi, idealini, terör yoluyla uygulamaya çalışan düşman karakter olarak karşımıza çıktı. Bu filmlerin birçoğu, Oscar törenlerinde ödülle şereflendirildi (Hasdemir, 2014).

Hollywood sinemasının en temel prensibi aslında ne gösterdiği değil, neyi ne zaman gösterdiği olmuştur. Çünkü dünya üzerinde herhangi bir olay, tutum ya da bir tepki gerçekleştiğinde Amerika, kendi görüşü ve ideolojisine uygun gördüğü filmleri piyasaya sürmekte ya da çekmektedir. $\mathrm{Bu}$ bağlamda Hollywood sinemasının kırdığı gişe rekorları ya da yıldız oyuncuların popüler olması gibi etkenlerin hepsi Amerika'ya propaganda malzemesi vermektedir. Milyonlarca insanın izlediği bu filmlerde görülen eşyalar, arabalar, kıyafetler ve marka reklamları binlerce insan tarafından satın alınmakta ve toplumların alışkanlıklarını değiştirmektedir. Yüzlerce insanın beğenerek izlediği ve takip ettiği karakterlerin sembollerini yansitan ya da taşıyan ürünler, filmler ile piyasaya sürülmekte ve devlet sermayesi bu şekilde kar etmektedir. Ticari ürünleri satın almanın yanı sıra bu karakterlerin bağımlılık derecesinde takip edilmesi parasosyal bir etkileşimin oluşmasına neden olmaktadır. Amerikan Hollywood sineması bu şekilde kendi yaşam tarzını ve kültürünü, tüm dünyaya yaymak için kullanmakta ve bunun sonucunda toplumlarda Amerika'ya benzer kültürel bir yansıma görülmektedir. Hollywood sineması dışarıdan bakıldığında sadece bir güldürü ve eğlence aracı olarak düşünülmesine rağmen, devlet politikaları doğrultusunda kullanıldığı bilinmekte ve belirli 
tarihi olaylar dizininde çekilen filmler incelendiğinde, bu açıç̧a görülmektedir. Örneğin western olarak bilinen kovboy filmlerinde yer alan ırkçı yaklaşım, silahlı-asi hareketler, milli bütünlük ve askeri değerler gibi temalar, izleyiciye benimsetilmeye çalışılmaktadır. Milli bütünlük ve askeri değerler söz konusu olduğunda çekilen tüm macera filmlerinde yer alan CIA, FBI gibi devlet bütünlügünü sağlayan polislerin daima bir olay karşısında her şeyi çözmesi ve en ufak bir sorunda orada olmaları, aslında Amerikan'ın halka karşı güven aşılama politikası olduğu bilinmektedir. Anlatı yapısı olarak daima geleneksel klasik anlatı biçimini tercih eden Hollywood sineması, bu yöntemle özdeşleşmeyi daha rahat kurmuş ve amaçlarına yönelik yıldız oyuncu sistemini inşa etmiştir. Filmlerinde iyi ve kötü karakterler kesin bir çizgiyle ayrılmış olup, daima çatışma sonrası mutlu sonla biten Hollywood sineması, Amerika'nın siyasi durumundan fazlasıyla etkilenmekte ve bu durum dışardan sadece film karakteri gibi görünen Rambo, Superman, Rocky ve Batman gibi süper kahramanların doğmasına neden olmuştur. Bu karakterler daha çok diş tehditlere karşı bir güç gösterisi olarak çekilen filmlerdir. Örneğin 11 Eylül saldırıları sırasında casuslarla mücadele ettiği görülen James Bond karakteri, 90 sonrasında Amerikan'ın dış politikaları doğrultusunda uluslararası teröristlerle mücadele etmeye başladığı görülmektedir. 'Soğuk Savaş sonrasından 11 Eylül saldırısına kadar olan dönem içerisinde Hollywood Sineması ABD’nin dünyada tek güç olduğuna dair anlatımlar içeren filmler çekerken, 11 Eylül sonrasında özgürlük, terör temalı filmler çekmiştir' (aktaran: Akyıl, 2017, s. 135). Aynı zamanda çalışmamızda yer alan 'The Green Berets (Yeşil Bereliler)' filmi ile Vietnam savaşında birçok erkeği savaşa katılmak ve ardından Amerika’nın kronik savaş davası için canlarını vermek üzere John Wayne gibi efsanevi bir karakter üzerinden tatlılıkla ikna etmiştir (Hagopian, 2018). Bu tip filmlere genel olarak bakıldığında ırkçılık ve milliyetçilik gibi duygularla ilgili unsurların ön planda olduğu görülür ve bu nedenle birçok Hollywood filmi sosyal mesajlar taşımakta birlikte toplum üzerinde ideolojik baskılar yaratmaktadır. Eski bir CIA direktörü Amerikan’ın yürüttüğü propaganda yöntemleriyle ilgili şu sözleri söyler: 'Amerikan halkının inandığı her şey sahte olduğu an, yanıltma haber kampanyamızın tamamlandığını anlayacă̆ız.' (Hagopian, 2018). Bu bağlamda incelenen Amerika ve Hollywood sineması kendi de dâhil olmak üzere tüm dünya geneline çeşitli vaatler vermiş ve özellikle savaş dönemlerinde birçok gencin askere gitmesini sağlayarak savaşta ölmesine neden olmuştur. Bunun için askeri ve kültürel propaganda yöntemlerini daha fazla kullandığı görülen Hollywood sineması, genel olarak karma bir propaganda yöntemi uygulayarak stratejik, uzun vadeli bir propaganda yapmaktadır. Çalışmamızın son bölümünde propaganda yöntemlerinin Hollywood sinemasında nasıl uygulandığı örnek 'Yeşil Bereliler' filmi üzerinden ele alınılıp, sahne analizleri yapılacaktır. 


\section{'Yeşil Bereliler' Filminin Propaganda Etkisi Açısından Analizi Filmin Künyesi}

Yönetmen: Ray Kellogg, John Wayne, Mervyn LeRoy

Senarist: Robin Moore

Vizyon: 1968 (USA)

Süre: $142 \mathrm{dk}$.

Dil: İngilizce

Yapım: USA

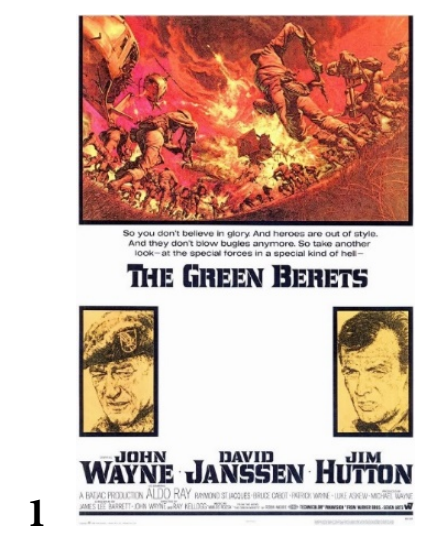

Şekil 1. Yeşil Bereliler (The Green Berets) Film Afişi

Erişim Tarihi: 28.05.2018, https://imdb.com

Amerikan Ordusu Özel Hareket Birlikleri olan 'yeşil bereliler', savaşlar dönemleri için eğitilen, 1952 yılında Albay Aaron Bank tarafından kurulmuş bir birliktir (Vikipedia, 2018). İlk olarak kendini Vietnam savaşında halka gösteren bu birlik, 1968 yılında John Wayne tarafından 'The Green Berets' olarak filme alınmıştır. (IMDb, 2018). Bu doğrultuda 'Amerika Silahlı Kuvvetleri, askerlerini ve büyük miktardaki teçhizatı, Amerika Birleşik Devletleri’nin Vietnam Savaşı'nı öven John Wayne'nin Yeşil Bereliler filmi için seferber etmiştir' (Yılmaz, 2007, s. 65-68). 19631973 yıllarında İkinci Çinhindi Savaşı olarak da bilinen Vietnam Savaşı; Kuzey Vietnam, Çin ve Sovyetler Birliği ile Amerika Birleşik Devletleri ve Güney Vietnam arasında yaşanırken, Amerika bu savaş nedeniyle ortalama altmış bin askerini kaybetmiştir. O dönemde asker sayısını arttırabilmek için propaganda amacıyla 'Yeşil Bereliler' filmini çekerek halkın kafasındaki soru işaretlerini yok etmiş ve savaşın haklı sebeplerini ortaya koymuştur. Başından sonuna kadar askeri propaganda yapan bu film, tamamıyla yeşil bereliler üstüne kurulu ve onların Güney Vietnam'ın yanında özgürlük ve demokrasi için savaşmasını konu almaktadır. Gerçek olaylardan esinlenerek çekilen bu film, Kuzey Vietnam askerlerinin orada yerel halka yaptıkları toplu katliamları ve işkenceleri birebir göstermektedir. Savaş zamanında 'Vietkonglar (Kuzey Vietnamlılar), akla gelebilecek her türlü işkenceyi ele geçirdikleri Amerikan askerlerine yapmaktan geri kalmamış, keza Amerikan askerleri de yakaladıkları Vietkonglar'ı diri diri helikopterle alçaktan (ölümleri geç ve can çekişerek olsun diye) atmışlardır. Toplu halde yapılan işkenceler, insanları canlı canlı yakmalar, biyolojik saldırılar, napalm bombaları, köy baskınları, toplu cinayetler ve yağmalar sıradan hale gelmiştir. Ray Kellog ve John Wayne tarafından 
çekilen film, yeşil berelilerin bir tanıtım organizasyonuna gelerek kendilerini tanıtmalarılya başlamaktadır. Bu sahnede bir düzine askerin ayrı ayrı uzmanlık alanlarına göre eğitim aldıkları ve farklı diller bildikleri yansıtılmak istenmiştir. Amerikan halkı arasında kendilerini tanıtan, yeşil berelileri dinleyen gazeteciler onlara Vietnam savaşı hakkında sorular sorarlar ancak Amerika basınının yapılan bu müdahaleye karşı oldukları oldukça net bir şekilde gözükmektedir. Yeşil bereliler savaşa girmelerinin sebebini kadınların ve çocukların katledilmesi, halkın işkence görmesi olarak açıklar ve diğer devletlerin savaşa dâhil olduklarını kanıtlamak için önlerine savaş alanında buldukları başka milletlere ait silahları atarlar. $\mathrm{Bu}$ doğrultuda yeşil bereliler savaşa müdahale etme gerekçelerini Amerika'nın 11 yıl süren kurtuluşu için verdiği mücadele ile bir tutmuşlardır. Böylece izleyiciye savaşa neden girdikleri açıklanmış ve o dönemde savaşa gönderilen yeşil bereliler daha yakından tanıtılmıştır.

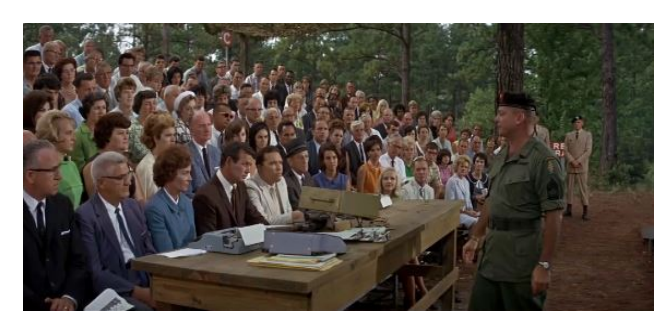

Şekil 1. Yeşil Bereliler (1968) - Tanıtım Sahnesi

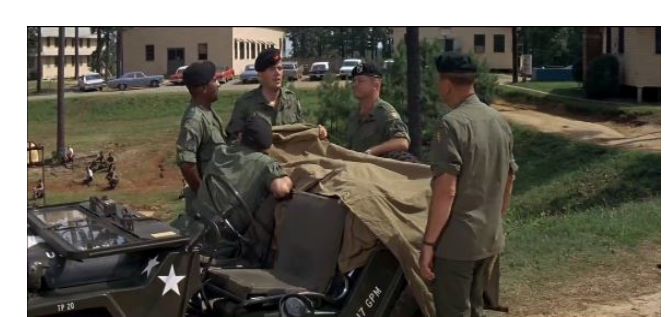

Şekil 2. Yeşil Bereliler (1968) - A Takımı

Başrol oyuncusu olan John Wayne, Albay Mike karakteri olarak karşımıza çıkar ve savaş ile ilgili toplantıdan çıkan Albay, tanıtımın yapıldığı alanda görülür. Tanıtım bitiminde bir gazetecinin yanına gelerek ona savaşı sorması üzerine, daha önce Güney Asya bölgesinde bulunup bulunmadığını sorar ve hayır cevabını aldığında gülümseyerek yanından ayrılır. Çünkü bu sahnede izleyiciye daha önce orada olmayanların savaşta yaşananları asla tam anlamıyla bilemeyecekleri, basının her dediğine inanmamaları ve halka karşı 'biz oradaydık, biz biliriz' imajı yansıtılmak istenmiştir. Bir sonraki sahnede yeşil bereli asker, Albay'ın yanına gelerek Vietnam Savaşına gitmek için gönüllü olmak ister. Onu kabul eden Albay, akla gelebilecek her şeyi bulabilmesiyle mimlenmiş olan son adayı uzaktan diğer takım arkadaşlarına izletir ve onu da takıma dâhil eder. Devamında Albay gecenin bir vakti tüm koğuşu kaldırarak Vietnam'a yola çıarak Amerika'dan ayrılırlar. Güney Vietnam'da Amerika'nın kurmuş olduğu askeri üsse iniş yapan Albay ve takımı, belli alanlarda ölen askerlerin isimleri verilmiş tabelalarla karşılaşır. Öyle ki bir sahnede bir yeşil bereli, Albay’a öldüğü takdirde istediği ismin yazılması için ricada bulunmaktadır. Böylece izleyicinin gözünde yeşil bereliler kutsallaştırılarak, öldükten sonra da isimlerinin hatırlandığı ve unutulmadıkları hissi verilmektedir. 


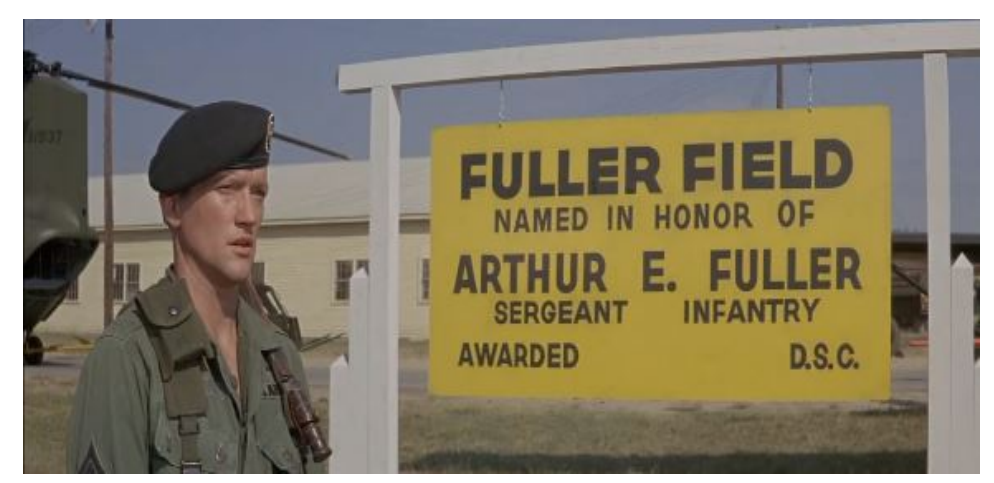

Şekil 4. Yeşil Bereliler (1968) - İsim Plaketleri

Albay üsse indiğinde birlikte çalışacağı Albay Cai'dan son durumla ilgili bilgi alır ve kurulan kamplara gitmek üzere A takımıyla birlikte yola çıkacakları sırada, tanıtım sırasında savaşla ilgili sorular soran Gazeteci Bay Beckworth'de yanlarına gelerek onlarla gitmek istediğini söyler. Başta asker alanlarının sivillere göre olmadığını vurgulamasına rağmen gazetecinin ısrarı üzerine gelmesine müsaade eder. Gerçekleri anlatma ve propaganda amacı taşıyan filmin bu sahnesinde, gazeteciyi büyük bir rahatlıkla aralarına almaları ve savaş alanına götürmeleri izleyici tarafından güvenoyu sağlamaktadır. Devamında, henüz tamamlanmamış olan kampa iniş yaparlar ve etrafta güvenlik kontrolü yapan Albay, kampı geliştirmek için çalışmalar başlatarak herhangi bir işgal durumunda nasıl önlemlerin alındığını öğrenir. Devamında, kamp alanında bulunan ve ailesi Vietkong (Kuzey Vietnamlılar) tarafından öldürülmüş yetim bir çocuk olan Hamchunk, her şeyi bulan Peterson ile karşılaşır ve işi gereği tercümanlık yapması için çocuğu kullanabileceklerini söyler.

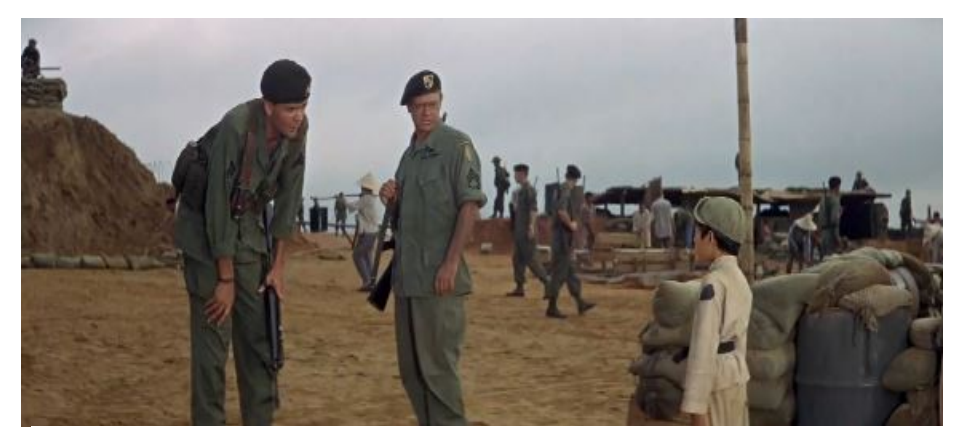

Şekil 5. Yeşil Bereliler (1968) - Peterson ve Hamchunk

Albay sonraki sahnede renkli dumanları kullanarak kampa güvenli giriş yapan devriye ekibinin başında bulunan, aynı zamanda kamp komutanı olan Tran Nim ile tanışır. Onunla etrafta bulunan tüm köylüleri kamp alanına çağırma fikrini paylaşır. Bu fikir hem kampın hızlı tamamlanması için hem de halkı güvende tutmak için düşünülmektedir ancak aynı akşam Vietkong tarafından kampın sadece haber sığınağı, revir ve takım evi bombalanır. Nokta atışıyla bu bölgelerin özellikle bombalandığını fark eden Albay, içeride bir köstebek olduğunu anlar ve patlama sonucu ertesi gün evine dönecek olan Yüzbaşı hayatını kaybeder. Ertesi sabah gece olup 
bitenlere tanık olan gazeteci, etraftaki Güney Kore askerleriyle sohbet eder ve Amerika'nın getirmiş olduğu helikopterler için onlar olmasa savaşı kazanamayız vurgusu yaparlar. Dönemin şartlarında ABD tarafından sağlanan güvenlik yardımı için getirilen silahlar, savaş boyunca Güney Kore'nin şartları eşitlemesine yardımcı olduğu bilinmektedir ve filmin birçok sahnesinde bu önem, farklı şekillerde vurgulanmaktadır. Sahnenin devamında ise helikopterler, etraftaki arazide bulunan Vietkong'luların inşaa ettiği köprüyü fark ederler ve bombalayarak karşı kıyıya geçmelerini önlerler.

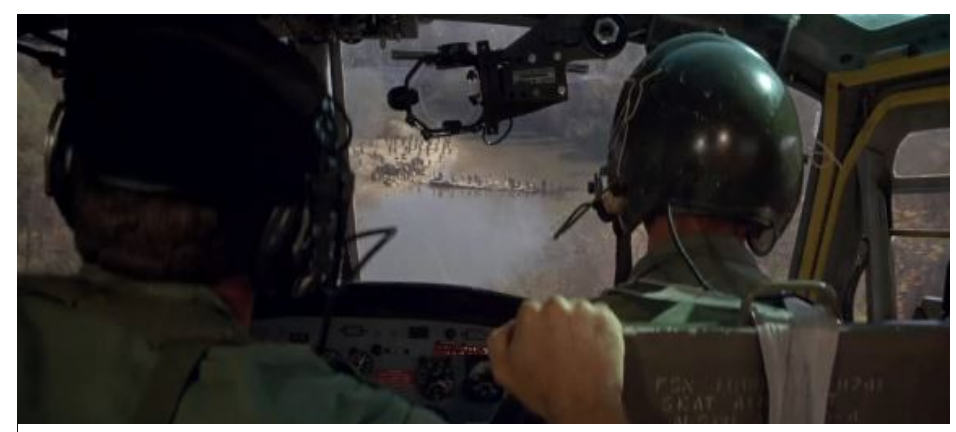

Şekil 6. Yeşil Bereliler (1968) - Helikopter

Akşam olduğunda Peterson'ın odasına bir yeşil bereli gelir ve odasındaki eşyaları nerden bulduğunu sorar. Savaş alanında olduğu halde sivil gibi davrandığını söyleyen askere karşı oldukça rahat bir tutum sergileyen Peterson, Hamchunk ile birliktedir. Başta çocuğu yanında istememesine rağmen Peterson gece onun yalnız yatmasına göz yumamamış ve yanına çağırmıştır. Filmin bu sahnesinde Peterson ile Hamchunk arasında kurulan bağ, Amerikan askerlerinin sadece savaşmaktan ibaret olmadıklarını vurgulamak ve herkes gibi bir insan olarak merhametli olduklarını göstermek amacıyla öyküye eklenmiştir. Ertesi sabah kamp alanına gelenleri karşılayan Albay, getirdikleri makine ile kampın etrafında görüşü engelleyen ağaçları temizletir ve bu esnada kamp alanında şüpheli davranan bir asker yakalanır ve içlerindeki köstebek ortaya çıkar. Yakalanan köstebeği öldürme girişimlerinden dolayı rahatsız olan gazeteci, Albay'la konuşur ancak Albay ona adamın cebinden çıkan çakmağı verir ve çakmağın kafası kesilmiş bulunan askere ait olduğunu söyleyerek yanından ayrılır.
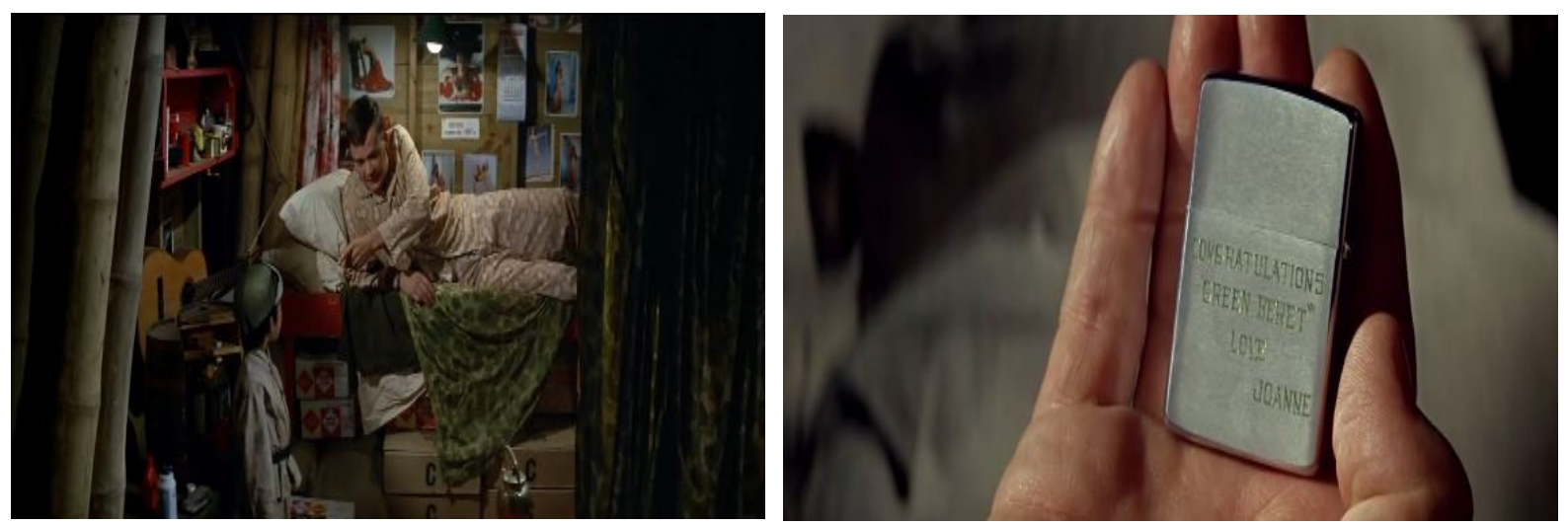

Şekil 3. Yeşil Bereliler (1968) - Peterson ve Hamchunk Şekil 4. Yeşil Bereliler (1968) - Çakmak 
Sahnenin devamında, yerel halka yardım eden ve hasta çocukları kontrol eden doktor gösterilmektedir. Çocuklara karşı sıcakkanlı davranışılla onları güldüren doktor, aynı zamanda revirde yatan askerleri de tedavi etmektedir. Sahnenin devamında kamp alanının kapısına ellerinde Vietkong'luların ormana kurdukları tuzaklar yüzünden yaralanmış bir çocuk ve bir grup köylü gelir ve doktor hemen müdahale eder. Albay ise onlara koruma ve yiyecek sağlayabileceklerini söyler ve ertesi gün devriye geleceklerini belirtir. Devriye için gittiklerinde ormanda bir sürü hazırlanmış tuzakla karşılaşırlar, köye vardıklarında ise iyileştirdikleri çocuk dâhil tüm erkekleri katledilmiş olarak bulurlar.

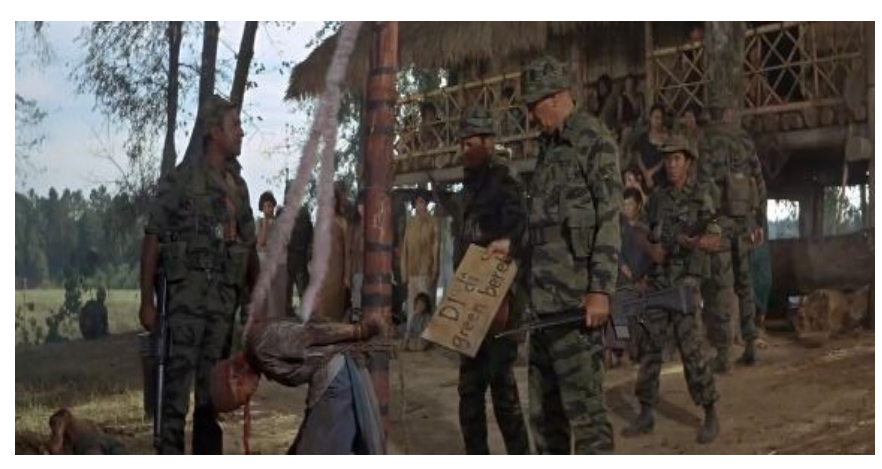

Bu katliamı gören gazeteciye Albay, en son gittiği köyde neler olduğunu anlatır. Anlattıkları, burada yaşananların çok daha kötüsüdür. Ardından kamp alanına sağ kalan kadın ve çocuklarla dönen Albay, bir sonraki sahnede şehirde bir mekânda görülmektedir. Yanında bulunanlar ona uzakta bir masada yemek yiyen ailesi Vietkonglular tarafından öldürülmüş olan Lin adında kadını göstererek, yanında oturan çift taraflı bir ajanla birlikte onlar için çalıştıklarını söylerler.

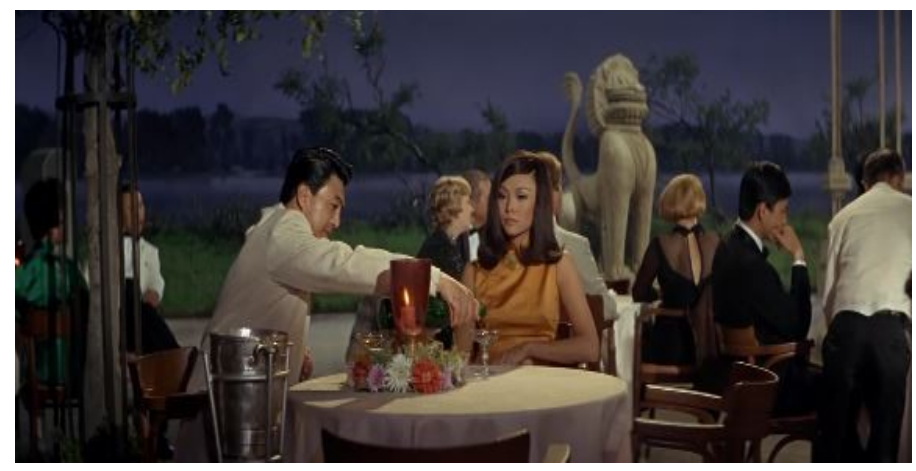

Şekil 5. Yeşil Bereliler (1968) - Lin

Albay yeşil berelilerin yanına gelmesi üzerine onlarla birlikte kamp alanına döner. O sırada kamp alanında bir hareketlenme söz konusudur. Gözcü kulesinde bulunan asker ormanda bir hareketlenme görür ve askerlerin konumunu sessizce ona göre yönlendirir. Kamp alanında Vietkonglularla çatışma içine giren askerler, Albay’ı destek ekiple birlikte içeri alabilmek için onlara pusu kurarlar. Kamp alanının işgal yönüne göre içerdeki sivilleri yönlendirdiği sırada Hamchunk'un köpeği saklandıkları yerden çıkar ve Hamchunk köpeğinin peşinden gider ve Peterson onu köpeğine mezar yaparken bularak savaş alanından uzaklaştırır. 


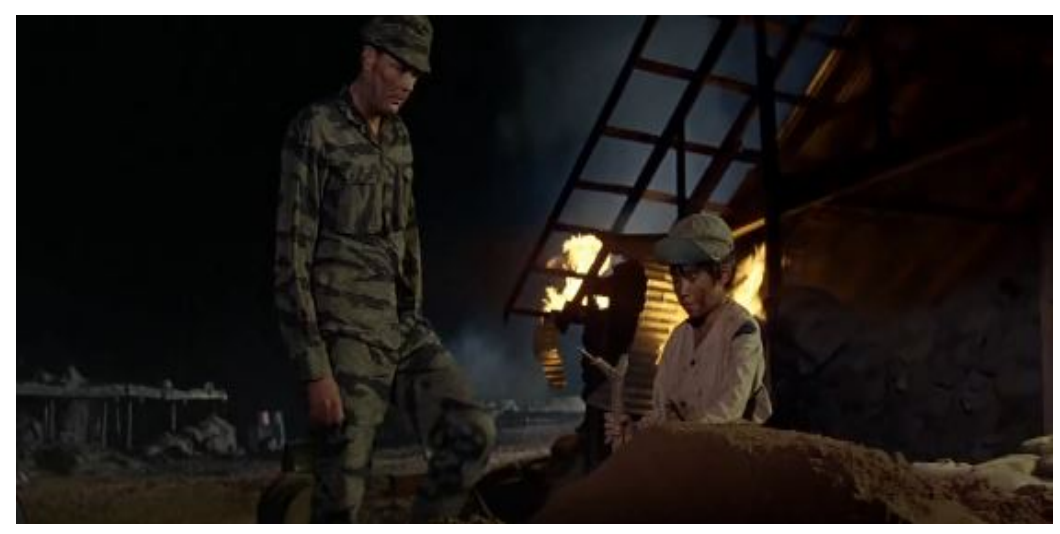

Sahnenin devamında destek ekiple buluşan Albay ve takımı, kurdukları hava pususu sonucu kamp alanına girmeyi başarırlar. Çatışma, gün doğumuna kadar devam eder ve içlerinde bulunan hainler tek tek ortaya çıkmaktadır. Gözcü kulesinin de yıkılması üzerine kamp alanından geri çekilmek zorunda kalan Albay, yeşil berelilere imha emrini verir ve sivil halkla birlikte kamp alanından ayrılırlar. Amerikan üssüne sivil halkı götüren uçakların birine Hamchunk'nda binmesini sağlayan Peterson, onun güvende olmasını sağlayarak takım arkadaşlarının yanına döner. Bu esnada Vietkong'lular kamp alanında zaferlerini kutlarken ve ölen askerlerin eşyalarını yağmalarlarken gösterilmektedir.

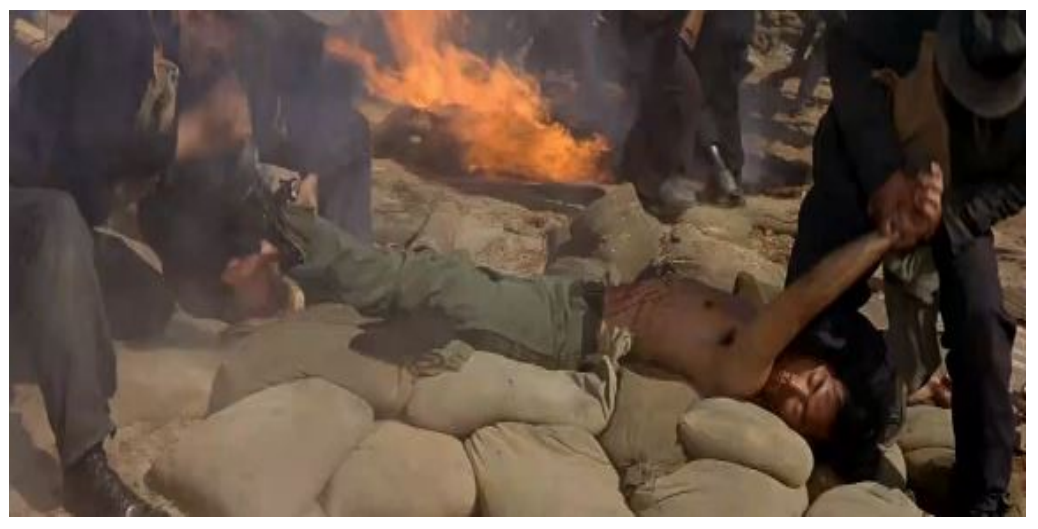

Sekil 6. Yesil Bereliler (1968) - Yă̆malama Sahnesi.

Bunun üzerine Albay bir hava saldırısı planlar ve o sırada kampta bulunan herkesi kurşuna dizer. Kamp alanına geri dönen askerler etrafı temizlerken, Albay, Vietkong'luların astığı bayrakları geri indirir. Ardından geri dönecek olan gazeteci ona haber olarak ne yazacağını sorar ve gazeteci ise hissettiklerini söylerse işinden olabileceğini söyler. Amerika'nın yaptığ müdahalede gazeteci olaylara bizzat kendi gözüyle gördüğü için ikna olmuştur, bu film ile de izleyiciye Vietnam'da yaşananlar gösterilmek istenmiştir. Devamında Albay çatışma sonrası ağır yaralanan askerinden yazdırmak istediği ismi öğrenir ve söz verdiği isim plaketini yaptırır. Devamında ise bu savaşın son bulabilmesi için önceden beri Albay Cai ile planlanan gizli bir görev için üsten çağırılır. Vietkong'luların başında olan General Ti'yi kaçırma görevini üstlenen Albay ve takımı, ailesi öldürülen Lin ile gizlice anlaşma yaparlar. Planlandığı gibi yeşil bereliler, 
Vietkong askerleri onları fark etmeden General Ti'nin bulunduğu evin içine girerek onu dışarı çıkarmayı başarırlar ve yolda takip edilmemeleri için köprüyü patlatan yeşil bereliler, General Ti’i almaya gelen uçağa binmesini sağlarlar. Görevini başarıyla tamamlayan Albay, takımıyla birlikte üsse geri döner ancak görev esnasında kaybettikleri kişilerden biri olan Peterson'u Hamchunk'ın beklediğini görür ve yanına giderek onunla konuşur. Peterson'un cesur olduğunu söyleyerek yeşil beresini ona verir ve Hamchunk'a yeşil bereli olarak hitap eder. İkisinin sahil kenarında yürümesini izleyen kamera görüntüsü ile film bitirilir.

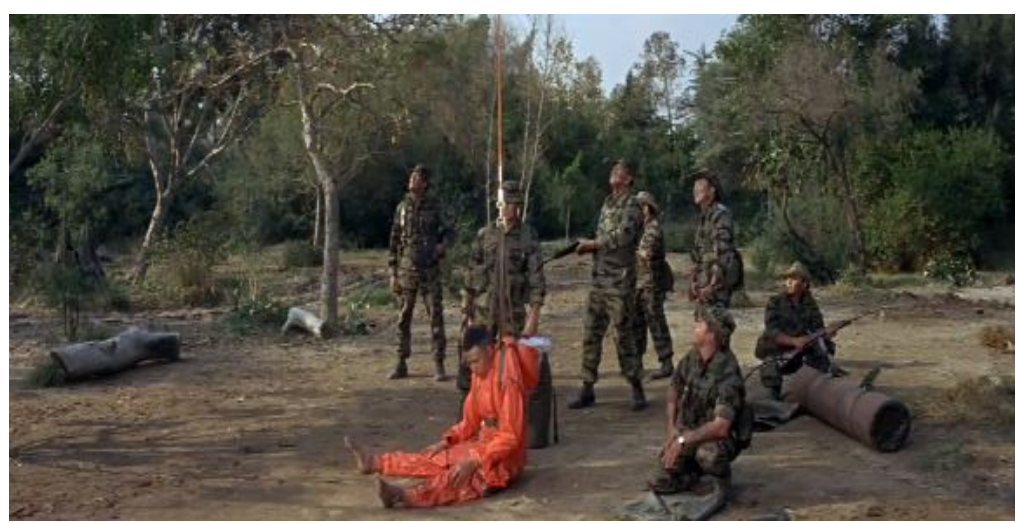

Görsel 7. Yeşil Bereliler (1968) - General Ti Teslim Sahnesi

Özetle 1964 senesinde Vietnam'da yeşil berelilerinde katıldığı Nam Dong, aslı savaştan ilham alınarak hazırlanmış olan bu film her yanıyla Amerikan askerinin propagandasını yapmaktadır. Silahları, güvenlik sistemleri ve kurdukları operasyonlar ile Amerika askerinin asla yenilmeyeceği ve son derece donanımlı olduklarının örneği olabilecek bu film, halkın Vietnam savaşı sırasında gönüllü olarak askere katılması ve basının söylediklerini dinlememeleri için yapılan bir propaganda filmi olmuştur. Film, halkı propagandaya maruz bırakarak o dönemde birçok gencin askere gitmesine ve Amerikan askeri olmakla ilgili oldukça büyük bir sempati oluşmasına yol açmıştır. Zamanla savaşın uzun sürmesi, karşıt olan kitlelerin büyüyerek daha bilinçli bir genç neslin oluşmasına katkı sağlamış ve Amerika, Vietnam’ı bölme düşüncesini gerçekleştirememiştir. Günümüzde Kuzey ve Güney Vietnam 1975 yllında birleşerek şuan Vietnam Sosyalist Cumhuriyeti olarak yönetilmektedir.

\section{Sonuç}

İnsanların toplum olarak var olması ve bireylerin birbirinden etkilendikleri bilinen bir gerçektir. Bireylerin birbirlerini ikna etme, hükmetme ve yönlendirme arzusu yaşamın her alanında görülmekte ve geçmişe bakıldığında insanların bu tutumlarının savaşların başlamasına ve bitmesine neden olduğu görülmektedir. İnsanların zaman geçtikçe birbirleriyle olan iletişiminin kolaylaşması ve teknolojinin gelişmesiyle birlikte var olan kitle iletişim araçları, egemen güçler ya da kişiler tarafından toplumları kontrol etmek için birer propaganda aracına dönüştürülmüştür. İnsanları yönlendirebilmek için farklı teknikler uygulayan bu kişiler ya da belli çevreler, kendi fikirlerini benimsetmek ve yaymak için gazete, radyo ve televizyon gibi 
görsel ve işitsel iletişim araçlarından faydalanmışlardır. Sinemanın ortaya çıkması ve insanlar tarafından ilgi görmesiyle birlikte film içerikleri de propagandaya dâhil olmuş ve ülkeler bu durumu kendi ideolojileri doğrultusunda firsata çevirmişlerdir. Kitleler arası daha kolay iletişime geçebilmesi için filmlerin ülkeler arası ücretleri bilinçli olarak kaldırılmış ve kolaylık sağlanmıştır. Dolayısıyla aynı zamanda eğitsel bir araç gibi görünen sinemanın etkinliği dünya genelinde artarak ortaya çıtı̆̆ bu zamandan beri devam etmekte ve istenildiği gibi daha fazla insana ulaşmaktadır. Bu doğrultuda ticari bir endüstriye dönüşen Hollywood sineması, Amerika tarafından uluslararası bir algı yönetim aracı olarak kullanılmaktadır. Sıklıkla savaş dönemlerinde karşılaşılan ve siyasi amaçlarla kitleleri manipüle etmek ya da yönlendirmek için kullanılan Hollywood sineması, propaganda aracı olarak kullanılmaktadır. Propaganda sinemasının altın çağlarını yaşatan Lenin ve Hitler'den sonra Hollywood sineması önemli temsillerden biri haline gelmiştir. Hollywood sinemasının üçüncü dünya ülkeleri üzerindeki kültürel baskı ve Amerikan hayat tarzının empoze edilmesi gibi çalışmalar, filmlerde yer alan karakterler ve yıldız oyuncu sistemiyle desteklenmektedir. Araştırma kapsamında ele alınan 'Yeşil Bereliler' filmi incelendiğinde, Hollywood sinemasının askeri propaganda yapmak için bu filmi çektiği anlaşılmaktadır. Vietnam Savaşı döneminde halkın askerlere karşı bir sempati içine girmesi ve gençleri asker olmaları için teşvik etmesi amacıyla yapılan bu film sayesinde Amerika'da binlerce genç o dönemde hayatını kaybetmiştir. Buna benzer biçimde Hollywood ve Amerikan Sineması, Nazi ve Almanya Sineması ve Sovyet Rusya Sineması gibi dönemin büyük devletlerinin sinemayı savaşlar üzerinden şekillendirerek içine kültür, rrkçılık, terörizm ve insan hakları gibi unsurlar ekleyerek şekillendirdiği görülmektedir. Bu doğrultuda sinemanın toplumsal olaylara göre şekillendiği ve değişime uğradığı tespit edilmiştir.

\section{Kaynakça}

Akyıl, L. (2017). Uluslararası İlişkilerde Algı Yönetimi Aracı: Propaganda Sineması. International Journal of Interdisciplinary and Intercultural Art, 2(2), 129-139.

Bektaş, A. (2002) Siyasal Propaganda. İstanbul:.Bağlam.

Bıçakçı, İ. (2003). İletişim ve Halkla İlişkiler. İstanbul:.Media Cat.

Doğan, İ. C. (2014). Propaganda Aracı Olarak İnternet: Kayseri İli Merkez Seçmeni Üzerine Bir Alan Araştırması. Yayımlanmamış Yüksek Lisans Tezi, Selçuk Üniversitesi, Konya.

Dorsay, A. (1984). Sinema ve Çă̆ımız-1. İstanbul: Hil.

İnceoğlu, M. (1985). Güdüleme Yöntemleri. A.Ü. Ankara: Basın-Yayın Yüksekokulu.

Jowett, G.S. ve V. O’Donnel. (2012). Propaganda and Persuasion. Fifth Edition, USA: Sage. 
Lerner, D. (2000). Propagandada Etkinlilik: Şartlar ve Değerlendirme, (Ed.) Ünsal Oskay, Kitle Haberleşme Teorilerine Giriş. İstanbul: Der.

Özsoy, O. (1998). Propaganda ve Kamuoyu Oluşturma. İstanbul: Alfa.

Tarhan, N. (2006). Psikolojik Savaş, Gri Propaganda. İstanbul: Timaş.

Valantin, Jen, M. (2006). Küresel Stratejinin Üç Aktörü: Hollywood, Pentagon ve Washington, (Ömer Faruk Turan(Çev.). İstanbul: Babıali Kültür.

Yaman, Ö. M. (2007). Bir İktidar Aracı Olarak Propaganda. Yayımlanmamış Yüksek lisans Tezi, Selçuk Üniversitesi, Konya.

Yılmaz, S. (2006). 21. Yüzyılda Güvenlik ve İstihbarat. İstanbul: Alfa.

\section{Elektronik Kaynaklar}

Hagopian, Joachim. (2018). Pentagon'un propaganda aygıtı: Hollywood. Erişim Tarihi: 11.05.2018 https://goo.gl/hbGfb4

Hasdemir, Furkan (2014). Hollywood'un Uçakları Müslümanlara Çarptı. Erişim Tarihi:11.05.2018 https://goo.gl/dz3Rg1

https://www.imdb.com/title/tt0063035/

IMDb. (2018). Soy Cuba. Erişim Tarihi: 11.05.2018, https://goo.gl/ZVGHuc

Odabaş, Battal. (2007). Propaganda Sineması. Erişim Tarihi: 09.05.2018 https://goo.gl/2TTHTv

\section{Film Kaynakçası}

Kellogg, R., Wayne, J., LeRoy, M. (Yönetmen). (1968), Yeşil Bereliler (Film), USA, Warner Brothers Burbank Studios. 